\title{
Features of the correction \\ of the emotional sphere of nurses
}

\section{E. A. Vinarchik ${ }^{1}$}

${ }^{1}$ Vladimir State University named after Alexander and Nikolai Stoletovs, 87 Gorky street, Vladimir 600000, Russian Federation

DOI: 10.18255/1996-5648-2021-2-268-275

Research article

Full text in Russian

The article presents the results of research and correction of the emotional sphere of medical personnel. The nurses features of emotional experiences with different experience of professional activity have been studied. A correction program was developed and carried out and reliable shifts were identified.

Keywords: snurse; emotions; experience; aggression; altruism

\section{INFORMATION ABOUT AUTHORS}

Vinarchik, Elena A. E-mail: elena-vinarchik@rambler.ru

Cand. Sc. (Psychology), Associate Professor 


\section{Коррекция эмоциональной сферы медицинских сестер с разным стажем профессиональной деятельности}

Е. А. Винарчик ${ }^{1}$

${ }^{1}$ Владимирский государственный университет имени Александра Григорьевича и
Николая Григорьевича Столетовых, ул. Горького, 87, Владимир, 600000, Российская
Федерация

DOI: 10.18255/1996-5648-2021-2-268-275

УДК 159.9

Научная статья

Полный текст на русском языке

В статье представлены результаты исследования и коррекции эмоциональной сфреры младшего медицинского персонала. Изучены особенности эмоциональных переживаний у медицинских сестер, имеющих разный стаж профессиональной деятельности. Разработана и проведена программа коррекции, выявлены достоверные изменения в уровне выраженности эмпатии.

Ключевые слова: медицинская сестра; эмоции; стаж; агрессия; альтруизм

ИНФОРМАЦИЯ ОБ АВТОРАХ

Винарчик, Елена Анатольевна | E-mail: elena-vinarchik@rambler.ru

Кандидат психологических наук, доцент

Постановка проблемы исследования. Медицина - это та сорера деятельности, где доминируют отрицательные эмоциональные состояния. Пациенты ожидают от медицинского персонала заботливости, сочувствия [1]. Для лучшего понимания состояния больного медицинский персонал должен обладать высокой эмпатийностью. Чтобы избежать эмоционального выгорания, медперсоналу приходится выстраивать некий барьер психологической защиты от пациентов и «выключать» эмпатию. Не в меру сильная эмоциональность или эмоциональная заторможенность - это преграда для реализации конкретных и быстрых действий. Риск появления синдрома эмоционального выгорания [2] у медицинских сестер достаточно велик. Условия, в которых работает медперсонал, зачастую служат причиной развития выгорания. Медицинская сестра в процессе рабочего дня тесно взаимодействует с больными, которым нужны и внимание, и забота.

(C) Винарчик Е. А., 2021

Статья открытого доступа под лицензией CC BY (https://creativecommons.org/licenses/by/4.0/) 
Винарчик Е. А.

Методики и организация исследования. Психологическая диагностика проводилась с помощью следующих методик: опросник «Определение общей эмоциональной направленности» Б. И. Додонова; опросник уровня агрессивности А. Басса и А. Дарки; самооценочный тест «Характеристики эмоциональности» Е. П. Ильина; шкала дифференциальных эмоций (ШдЭ) К. Изарда; шкала эмоциональной возбудимости (ШЭВ); методы статистической обработки данных: анализ достоверности различий связанных выборок с использованием Т-критерия Вилкоксона [3].

Эмпирическое исследование проводилось на базе ГБУЗ ВО «Областная клиническая больница» в 2020 г. среди медицинских сестер с разным стажем профессиональной деятельности. В исследовании приняли участие 45 медицинских сестер - по 15 медсестер в каждой группе. Возраст испытуемых - от 21 года до 65 лет: 1 -я группа - стаж до 10 лет; 2-я группа - стаж от 11 до 20 лет; 3-я группа - стаж свыше 20 лет.

Результаты и их обсуждение. Нами были получены следующие результаты первичного эмпирического исследования.

С целью исследования общей эмоциональной направленности нами был проведен опрос по методике Б. И. Додонова. Установлено, что у медицинских сестер со стажем до 10 лет доминируют коммуникативные эмоции. Из этого следует, что для медицинских сестер характерна ярко выраженная потребность в общении (среднее значение - 6,73 балла). Необходимо также отметить высокие показатели по шкалам: альтруистические эмоции (для медсестер характерно стремление делать людям добро - среднее значение 5,47 балла); праксические эмоции (стремление активно действовать, реализовывать поставленные цели, достигать своих желаемых результатов - среднее значение 5,60 балла); романтическая эмоция (стремление к необычному, таинственному - среднее значение 5 баллов); гедонистические эмоции (потребность душевного и физического комфорта - среднее значение 6 баллов). Средние значения по остальным шкалам были такими: глорические эмоции (стремление получить признание, чувство гордости и превосходства над другими - среднее значение 2,00 балла); пугнические эмоции (потребность преодоления опасности, острых ощущений, азарте борьбы - среднее значение 1,00 балл); акизитивные эмоции (потребность коллекционировать - среднее значение 1,60 балла); гностические эмоции (потребность в новых знаниях - среднее значение 2,13 балла); эстетические эмоции (потребности воспринимать прекрасное - среднее значение 3,53 балла).

У медицинских сестер со стажем от 10 до 20 лет доминирует коммуникативная эмоция. Следовательно, для медицинских сестер характерно ярко выраженная потребность в коммуникации (среднее значение 6,60 балла). Также важно отметить высокие показатели: альтруистические эмоции (среднее значение 6,20 балла), праксические эмоции (среднее значение 5,60 балла), романтические эмоции (среднее значение 5,80 балла), эстетиче- 
Коррекция эмоциональной сферы медицинских сестер...

ские эмоции (среднее значение 6,20 балла); средние значения: глорические эмоции (среднее значение 1,93 балла), пугнические эмоции (среднее значение 4,27 балла), гностические эмоции (среднее значение 4,67 балла), гедонистические эмоции (среднее значение 2,33 балла); акизитивные эмоции (среднее значение $(-1,40)$ балла).

У медицинских сестер со стажем работы более 20 лет доминирует альтруистическая эмоция (среднее значение 6.00 баллов). Также следует отметить высокие показатели: праксические эмоции (среднее значение 5,60 балла); средние значения: глорические эмоции (среднее значение $(-0,27)$ балла), пугнические эмоции (среднее значение $(-2,27)$ балла), романтические эмоции (среднее значение 1,27 балла), акизитивные эмоции (среднее значение -1,20 балла), гедонистические эмоции - (среднее значение 2,53 балла), гностические эмоции (среднее значение 0,53 балла), эстетические эмоции (среднее значение 2,40 балла), коммуникативные эмоции (среднее значение 4,67 балла).

Для изучения уровня агрессивности нами была использована методика А. Басса - А. Дарки. В результате исследования установлено, что у медицинских сестер со стажем до 10 лет доминирует вербальная агрессия: медицинским сестрам характерно выражение негативных чувств через крик и через содержание словесных ответов (среднее значение 7,20 балла). Также нужно отметить высокое значение по шкале чувство вины: для медицинских сестер свойственно возможное убеждение в том, что они поступают неправильно. Ощущают угрызения совести (среднее значение 6,60 балла). Среднее значение по шкалам: физическая агрессия - использование фризической силы против другого лица (среднее значение 4,07 балла), косвенная - агрессия, окольным путем направленная на другое лицо или ни на кого не направленная (среднее значение 4,47 балла), раздражение. Для медицинских сестер характерны вспыльчивость, грубость (среднее значение 5,53 балла), подозрительность. Медицинским сестрам свойственно недоверие и осторожность по отношению к людям и убеждение в том, что другие люди планируют нанести вред (среднее значение 5.40 балла). Низкие показатели: негативизм - оппозиционная манера в поведении от пассивного сопротивления до активной борьбы (среднее значение 2,20 балла), обида зависть и ненависть к окружающим за действительные и вымышленные действия (среднее значение 3,87 балла). Индекс враждебности является нормой. Индекс агрессии является нормой.

У медицинских сестер со стажем от 10 до 20 лет доминирует чувство вины. Им свойственно возможное убеждение в том, что они являются плохими людьми, поступают нехорошо, вредно, злобно или бессовестно, испытывают угрызения совести (среднее значение 6,47 балла). Средние показатели: раздражение (среднее значение 5,67 балла), вербальная агрессия (среднее значение 5,33 балла), косвенная агрессия (среднее значение 4,07 балла); низкие показатели: фризическая агрессия (среднее значение 
3,87 балла), негативизм (среднее значение 1,87 балла), обида (среднее значение 3,40 балла), подозрительность - (среднее значение 3,67 балла). Индекс враждебности является нормой. Индекс агрессии является нормой.

У медицинских сестер со стажем свыше 20 лет доминирует чувство вины. Соответственно, им характерна агрессия, которая направлена на самих себя (среднее значение 6,73 балла). Низкие показатели: физическая агрессия (среднее значение 2,53 балла), косвенная агрессия (среднее значение 4,20 балла), вербальная агрессия (среднее значение 4,93 балла), раздражение (среднее значение 4,33 балла), подозрительность (среднее значение 3,87 балла), негативизм (среднее значение 2,87 балла), обида (среднее значение 3,40 балла). Индекс враждебности является нормой. Индекс агрессии ниже нормы.

В результате изучения данных, полученных при тестировании испытуемых по дифференциальной шкале эмоций К. Изарда, были получены следующие показатели. Установлено, что у медицинских сестер со стажем до 10 лет доминирует шкала интерес (среднее значение 9,27 балла). Также необходимо отметить высокий показатель шкалы радость (среднее значение 7,67 балла). Низкие показатели по шкалам: удивление (среднее значение 3,40 балла), горе (среднее значение 3,47 балла), отвращение - (среднее значение 3,07 балла), презрение - (среднее значение 3.13 балла), страх (среднее значение 3.00 балла), стыд (среднее значение 3,07 балла), вина (среднее значение 3,53 балла).

Установлено, что у медицинских сестер со стажем от 10 до 20 лет, доминирует шкала интерес - (среднее значение 10,27 балла). Также необходимо отметить высокий показатель шкалы радость - (среднее значение 7,80 балла). Среднего значения не выявлено. Низкие показатели по шкалам: удивление (среднее значение 3,00 балла); горе (среднее значение 3,00 балла); гнев (среднее значение 3,00 балла); презрение (среднее значение 3.00 балла); страх (среднее значение 3.00 балла); отвращение (среднее значение 3,00 балла); стыд - (среднее значение 3,33 балла); вина (среднее значение 3,53 балла).

У медицинских сестер третьей группы со стажем более 20 лет доминирует шкала интерес (среднее значение 10,13 балла). Также необходимо отметить высокий показатель шкалы радость (среднее значение 7,67 балла). Среднего значения не выявлено. Низкие показатели по шкалам: удивление (среднее значение 3,53 балла); горе (среднее значение 3,00 балла); гнев (среднее значение 3,00 балла); отвращение (среднее значение 3,00 балла); презрение (среднее значение 3,00 балла); страх (среднее значение 3,00 балла); стыд (среднее значение 3,00 балла); вина (среднее значение 3,00 балла).

Для изучения шкалы эмоциональной возбудимости (ШЭВ) нами была использована методика А. А Рукавишникова (модифкация). В результате проведенного исследования установлено, что у медицинских сестер с разным стажем профессиональной деятельности эмоциональная возбуди- 
Коррекция эмоциональной сферы медицинских сестер...

мость имеет низкий показатель. Несмотря на это, медицинские сестры со стажем до 10 лет более эмоционально возбудимы по сравнению с другими группами медицинских сестер.

Была разработана коррекционная программа и проведена тренинговая программа, включающая методы арт-терапии и музыкотерапии. По окончании программы тренинга была проведена повторная диагностика.

По результатам вторичной диагностики у медицинских сестер со стажем до 10 лет можно наблюдать следующие изменения по шкалам: альтруистические эмоции (среднее значение 6,20 балла), коммуникативная эмоция (среднее значение 7,47 балла), пугнические эмоции (среднее значение 0,73 балла), акизитивные эмоции (среднее значение 2,07 балла), гностические эмоции (среднее значение 3,40 балла), эстетические эмоции (среднее значение 4,07 балла), праксические эмоции (среднее значение 5,73 балла), романтическая эмоция (среднее значение 5,20 балла), гедонистические эмоции (среднее значение 6,47 балла), глорические эмоции (среднее значение 2,20 балла).

По результатам посттренинговой диагностики общей эмоциональной направленности у медицинских сестер со стажем от 10 до 20 лет можно отметить следующие изменения по шкалам: альтруистические эмоции (среднее значение 7 баллов), коммуникативная эмоция (среднее значение 7 баллов), праксические эмоции (среднее значение 6 баллов), пугнические эмоции (среднее значение 3,87 балла), гедонистические эмоции (среднее значение 3,00 балла), акизитивные эмоции (среднее значение $(-1,73)$ балла), гностические эмоции - (среднее значение 5,07 балла), эстетические эмоции - (среднее значение 6,40 балла), романтические эмоции (среднее значение 5,07 балла), глорические эмоции (среднее значение 1,33 балла).

По результатам повторной диагностики общей эмоциональной направленности у медицинских сестер со стажем более 20 лет можно отметить изменения в уровне выраженности таких эмоций как: коммуникативные эмоции (среднее значение 5,27 балла), праксические эмоции (среднее значение 6,20 балла), романтические эмоции (среднее значение 0,80 балла), гедонистические эмоции (среднее значение 3,47 балла), эстетические эмоции (среднее значение 3,07 балла), альтруистические эмоции (среднее значение 6,53 балла), пугнические эмоции (среднее значение $(-1,73)$ балла), акизитивные эмоции (среднее значение $(-1,73)$ балла), гностические эмоции (среднее значение 0,40 балла), глорические эмоции (среднее значение $(-0,73)$ балла).

Повторная диагностика уровня агрессивности у медицинских сестер со стажем до 10 лет с помощью методики А. Басса - А. Дарки также показала определенные изменения. Наблюдается снижение уровня выраженности показателей вербальной агрессии (среднее значение 6,07 балла), чувства вины (среднее значение 5,80 балла), физической агрессии (среднее значение 4,00 балла), косвенной агрессии (среднее значение 4,40 балла), раздражения (среднее значение 5,00 баллов), негативизма (среднее значение 
2,33 балла), обиды (среднее значение 3,80 балла), подозрительности (среднее значение 5,20 балла).

В результате проведения повторной диагностики установлено, что у медицинских сестер со стажем от 10 до 20 лет можно наблюдать снижение показателей по шкалам: вербальная агрессия (среднее значение 4,87 балла), чувство вины (среднее значение 5,20 балла), раздражение (среднее значение 4,93 балла), физическая агрессия (среднее значение 2,40 балла), косвенная агрессия (среднее значение 3,93 балла), негативизм (среднее значение 2,67 балла), обида (среднее значение 3,20 балла), подозрительность (среднее значение 3,33 балла). Индекс враждебности является нормой. Индекс агрессии является нормой.

Проведенная коррекционная работа позволила снизить уровень разрушающих эмоциональных переживаний у медицинских сестер со стажем от 20 и более лет. Достоверные изменения зафиксированы по таким шкалам как: чувство вины (среднее значение 5,80 балла), косвенная агрессия (среднее значение 3,93 балла), вербальная агрессия (среднее значение 4,33 балла), физическая агрессия (среднее значение 2,40 балла), раздражение (среднее значение 4,40 балла), негативизм (среднее значение 2,67 балла), обида (среднее значение 3,20 балла), подозрительность (среднее значение 3,33 балла).

По результатам повторной диагностики характеристик эмоциональности с помощью методики Е. П. Ильина установлено, что у медицинских сестер со стажем до 10 лет шкала интенсивность эмоций, также преобладает над другими шкалами, но её показатель стал ниже. Медицинским сестрам свойственны сильные эмоциональные переживания, склонность к глубоким переживаниям и проявлениям чувств (среднее значение 4,27 балла). Остальные шкалы имеют незначительное снижение результатов: эмоциональная возбудимость (среднее значение 3,60 балла), отрицательное влияние эмоций (среднее значение одинаково - по 3,47 балла), длительность эмоций (среднее значение 3,40 балла).

Посттренинговое тестирование медицинских сестер со стажем от 10 до 20 лет также позволяет сделать вывод об эффективности коррекционной программы. Сила переживаний медицинских сестер стала оптимальной (среднее значение 4,00 балла).

В результате повторного проведенного исследования установлено, что у медицинских сестер со стажем более 20 лет самый высокий показатель имеет отрицательное влияние эмоций (среднее значение 4,33 балла). Остальные показатели эмоциональной сферы стали оптимальными: эмоциональная возбудимость (среднее значение одинаково - по 3,53 балла), интенсивность эмоций (среднее значение одинаково - по 3,67 балла), длительность эмоций (среднее значение 2,87 балла).

Результаты повторной диагностики методикой К. Изарда показали, что у медицинских сестер всех трех групп можно наблюдать изменения. 
Коррекция эмоциональной сфреры медицинских сестер...

Установлено, что у медицинских сестер с разным стажем профессиональной деятельности эмоциональная возбудимость имеет низкий показатель. Помимо общих основных фундаментальных эмоций, для медицинских сестер с разным стажем характерна общая эмоциональная возбудимость, которая усиливает проявление других специализированных эмоций.

Методом математической статистики (критерий Т-Вилкоксона) доказан достоверный сдвиг в типичную сторону по большинству измеряемых параметров (альтруистическая, коммуникативная, глорическая, праксическая, пугническая, романтическая, акизитивная, гедоническая, гностическая, эстетическая направленности, вербальная агрессия, физическая агрессия, косвенная агрессия, раздражение, негативизм, обида, подозрительность, чувство вины, эмоциональная возбудимость, интенсивность эмоций, длительность эмоций, интерес, радость, удивление, горе, гнев, презрение, стыд, вина, эмоциональная возбудимость).

Выводы. Проведенное исследование показало, что коррекция эмоциональной сферы медицинских сестер необходима в силу преобладания ситуаций повышенного стресса, что сказывается на общем эмоциональном фоне персонала. Особенно эта необходимость возрастает в современных условиях пандемии. Однако психологического сопровождения без заинтересованности медперсонала недостаточно для выстраивания помогающих отношений, снижения стресса и стабилизации эмоциональной сферы. В результате повторной диагностики было установлено, что у медицинских сестер с разным стажем профессиональной деятельности эмоциональная возбудимость имеет низкий показатель На основании этих выводов можно сделать заключение об эффективности разработанной коррекционной программы.

\section{Ссылки}

1. Винарчик Е. А., Капустина В. А. Психология профессионального развития личности: учебное пособие. Владимир: Изд-во ВлГУ, 2020. 96 с.

2. Карпов А. В. Психологический анализ трудовой деятельности. Ярославль: ЯрГУ, 2016. 76 c.

3. Современные методы психологической диагностики: практикум / О. В. Филатова, Н. Ю. Литвинова, Е. А. Винарчик. Владимир: Изд-во ВлГУ, 2011. $296 \mathrm{c}$. 